DOI https://doi.org/10.30525/978-9934-588-80-8-2.2

\title{
FORMATION OF POLITICAL CULTURE IN STUDENTS OF HIGHER MILITARY EDUCATIONAL INSTITUTIONS
}

\author{
Vanovska I. M. \\ Candidate of Historical Sciences, \\ Leading Research Fellow at the Linguistic Scientific Research Department \\ Military Institute of Taras Shevchenko National University of Kyiv \\ Skriabin O. L. \\ Candidate of Historical Sciences, \\ Senior Research Fellow at the Linguistic Scientific Research Department \\ Military Institute of Taras Shevchenko National University of Kyiv \\ Kyiv, Ukraine
}

The real changes in military education are taking place against the background of the need to consistently strengthen the Armed Forces, compare the tasks of their modernization with socio-economic opportunities, sociocultural traditions, as well as the nature of potential threats and the dynamics of the international political situation. At the same time, such tasks as the transition to a professional army come to the fore; formation of a fundamentally new personnel policy and training system; updating the theory and practice of military construction; organization of structural restructuring of the army and military administration; increasing the prestige of military service; democratization and humanization of relations in the military; formation of public consciousness in the spirit of the need for armed protection of the national interests of the country. Thus, the competence of the military education system includes not only the implementation of professional educational programs in the field of military affairs, but also the formation of future officers system-forming socio-cultural structure, which determines the direction of political and professional socialization, the dynamics of social status and social mobility. values of professional activity of military, their formation as the person as a whole.

As a result of understanding modern realities, we come to the conclusion that a modern serviceman must have an activist political culture. The solution to this problem in the system of military education primarily concerns cadets of higher military educational institutions. Addressing the problem of formation of political culture required clarification of the formulation of basic conceptual positions and concretization of the scientific 
idea of the content of conceptual concepts: «culture», «political culture», «political culture of the individual» [2, p. 26].

Culture can be defined as a process of material and spiritual activity of people, as well as the result of this activity, which forms a set of socially significant values that determine both the external conditions of human life (objective world of culture) and the formation of man himself who creates them [3].

The political culture of a country is part of its general culture, the system of institutionalized political values, principles, norms and forms of society and the functions of the state. Political culture includes stable ideas, attitudes, ideas, skills, abilities, ie ingrained political consciousness and behavior of the subjects of social relations (individuals, groups, strata, etc.), as well as ways and methods of functioning of political institutions, especially for all state power [5].

Political culture covers only those manifestations of consciousness, behavior, functioning of the political system, which fix the stable, recurring links between the elements of the political process and thus further consolidate the characteristic political practices.

Under the political culture of the individual can be understood as an integrative quality of the social subject (cadet of the military university), in which synthesized political knowledge and skills, values, attitudes and beliefs, political experience, ultimately determine his political behavior.

The model of pedagogical process on formation of political culture at cadets of military high schools is presented as set of interconnected components: target (definition of a complex of pedagogical tasks which decision is directed on formation of consciousness and behavior of the cadet as the defender and the citizen of the country); meaningful (educational and extracurricular activities that should contribute to the awareness of cadets of their responsibilities for the defense of the Fatherland and their participation in the socio-political life of the country); organizational (the use of active forms of classes, the solution of the system of educational and political tasks) and effective (study and analysis of the effectiveness of the formation of political culture) [1, p. 79].

Pedagogical conditions for the implementation of effective formation of cadets of activist political culture is a large complex, which includes: the implementation of professional orientation of the humanities; ensuring the subjective position of the cadet in the study of humanities; inclusion of cadets in active social activities, creation of a heuristic educational environment, which forms the possession of cadets of military universities political culture within a specially designed pedagogical system, 
characterized by a scientifically sound structure and special ways to manage the process of its formation.

The main criterion for the formation of future specialists in activist political culture is their promotion to a higher level on conditionally identified indicators of its individual components: cognitive, valuemotivational and operational-activity.

The greatest efficiency in the process of cadets' development of political science knowledge, as well as norms and values of activist political culture was found in the use of electronic curricula, educational games and individual practical tasks - during the training tasks thinking in search of new ways to solve educational problems.

Individual passage of the whole decision-making process forms in cadets the ability to independently develop options for solving any problem. The following methodological techniques help to achieve this: individual development, report and defense by each cadet of the developed variant of the decision, its specification and processing, participation in development of the collective version, determining the most optimal option; educational game as a form of organization of educational activities includes an imaginary situation, game actions that must be performed and carried out by those who are taught.

Effective pedagogical means of forming activist political culture in cadets during the educational process are discussions, debates, use of practical tasks, electronic curriculum, educational games that provide problems, dialogue, debatability in the learning process and the formation of the subjective position of cadets.

It should be noted that the subjective approach to learning using a number of innovative pedagogical tools can be most effective in resolving the following contradictions related to the learning process: contradictions between the process of professional training (technical orientation of the university) and the humanitarian component in the training and education of a conscious citizen and a future officer who has, in addition to professional qualities, political competence, ability to educate subordinates; contradictions between political reality, which means extreme mobility, variability, poor predictability or completely unpredictability of political and social phenomena and processes that are the object and subject of political science itself, and the need to give students sufficient competencies for professional or interpersonal use. and educational contexts; contradictions between the postulates of political science and the real practice in which cadets are immersed - especially in terms of creating interpretive schemes of political reality, when there are obvious inconsistencies, which are taught in the course of political science, such as civil society values with Ukrainian 
reality. Therefore, the interest shown by cadets in politics and political science, as a science and discipline that studies this area of society; contradictions between the teacher's desire to teach political science courses as meaningfully and interestingly as possible and the different level of their perception by cadets (different level of motivation, abilities, etc.); between the desire and willingness of cadets to move to innovative (including information) learning technologies and the unwillingness or unwillingness of the teacher to do so (mirror option - the desire and attempts of the teacher to work «in a new way» and conservatism, which show cadets in relation to methods, which mobilize them for constant activity); between the requirements of modern teaching pedagogy to build the learning process within the subject relations and the attitude of many teachers to perceive the cadet only as an object of study, and the cadets - reluctance to move to their own active algorithm in organizing classes; between the pragmatic approach of the teacher to provide training in accordance with the necessary requirements and the importance of creating conditions in the educational process that ensure the creative self-development of the student cadet [4].

This is a contradiction between the pragmatic approach of «surrender and forget» and characterizes the civic personality by integrating the acquired knowledge and skills into the professional practice of the officer. Thus, the formation of political culture in the cadets of military universities - a complex, multi-stage process of active development of political knowledge, values and norms that exist in society, the formation of values are manifested in the responsible performance of military duty, responsibilities to protect the Fatherland and participation in the socio - political life of the country.

\section{References:}

1. Bebik V. Political science for politics and citizens / V. Bebik. - K. : МАУП, 2003. - 424 p.

2. Kokorska O. Political culture: theoretical and methodological problems / O. Kokorska, V. Kokorsky // Scientific notes. - 2002. - P. 24-28.

3. Lipset CM The role of political culture / CM Lipset. - Access mode: http://www.gumer.info/bibliotek_Buks/Polit/ Article / lip_rol.php

4. Polishchuk I. The concept of political culture: structural aspect [Electronic resource] / I. Polishchuk // Staff. - 2005. - Access mode: http://www.personal.in.ua/article.php?ida $=22$

5. Rudakevich O. Formation of national political culture in the context of the values of the European Union. [Electronic resource] Access mode: http://nbuv/gov/ua/j-pdf/Um_msm_2014_19(1)_39.pdf 